\title{
Technical Barriers to Trade of Leather and Footwear: Impacts and Challenges Posed by International Standards, Regulations and Market Requirements in Brazil
}

\author{
Mauro Silva Ruiz, Alexandre de Oliveira e Aguiar, \\ Pedro Luiz Cortez, Cláudia Echevenguá Teixeira \\ and Gustavo Silveira Graudenz
}

Additional information is available at the end of the chapter

http://dx.doi.org/10.5772/50575

\section{Introduction}

A technical barrier is a type of non-tariff barrier related to a technical standard, regulation or a market requirement applicable to features of industrial products, processes or methods of production aiming at protecting the environment and consumers. In this case it relates to restrictions imposed by international directives, standards and regulations, and market requirements regarding the presence of a number of chemical substances in leather (wet blue stage) and footwear, as well as physical and mechanical characteristics of soles and heels.

As the market globalization became more evident right after the Uruguay Round organized by World Trade Organization (WTO), several technical barriers showed up in the market of many products, most of them imposed by European countries. At first, these barriers were seen as protectionist measures most of them taking an environmental issue as some sort of appeal. One question frequently asked in the early nineties was: can an increase in the international trade result in more environmental degradation?

Although it is not quite clear in the surveyed literature, obstacles that in previous decades were seen as protectionist measures are being more and more seen as opportunities for companies and corporations that have been incorporating environmental management as a competitive advantage in their strategies. In fact, this issue is somewhat related to the controversial relationship between trade and development (Philip; Jeanet \& Finn, 2009). 
Braga and Miranda (2002) refers to Porter hypothesis that emphasizes the synergy effects between environmental regulation and competitiveness (Porter and Van der Linde, 1995). It means that the more companies go beyond the basic standards, improving their own environmental control and monitoring, the better their competitiveness in the marketplace.

The technical barriers with "green roots" in general have their birth in countries and economic blocks where the awareness of society of sustainable consumption started several years ago. Usually, the presence of the economic benefits of environmental regulations such as better distribution of natural resources or avoiding public health issues has already been perceived in these countries. Thus, the demand for environmentally friendly products and goods pushed regulations forward in these places firstly and in the countries from where they have been importing afterwards.

International trade is currently regulated by World Trade Organization. More than 150 state members are involved in the liberalization of international trade, particularly in the removal of unnecessary barriers to international trade and in the solution of disputes. Technical barriers are also discussed in this context.

One important aspect of directives that establish technical or environmental standards is that at first they violate two basic principles of the Technical Barriers to Trade (TBT) as it concerns to "no discrimination" and "harmonization of rules regulations and procedures". The first principle is violated particularly when a rule, regulation or a technical procedure is required to be followed by an exporting one that is less developed than the importing one. If violation can be proved by the reclaiming country, a round of negotiation will be settled by WTO to resolve the matter.

Fornasari Filho and Coelho (2002) point out that the WTO has been concerned with detecting, characterizing and eliminating restrictions or distortions of an environmental nature that can result in barriers to trade.

Presently there is a growing concern for environmental issues and the associated barriers to international trade in products coming from industrial sectors located in developing countries that could be affecting the environment. This is the case of the leather and footwear sector that can potentially have a heavy impact the environment due to a number of chemical substances used in the treatment of the hide and skin into processed leather.

Progressively, regulatory pressures coming from new rules and regulations resulting from both the international and domestic market forced the leather and footwear companies to introduce continuous improvements in their production processes reducing pollution at its source and also aggregating new technologies in the tanning process. On the other hand, footwear consumers worldwide are becoming aware of the environmental and health effects of the chemical substances used in leather processing. This has led to a more effective monitoring of the environmental effects caused by the leather and footwear industry especially in developed countries. 
Public pressure on tanneries and all industries that are leather users, including footwear factories, furniture, cars and clothes, has been intensified requiring them to use leather having reduced levels of hazardous substances.

One assumption of this chapter is that international standards, regulations and market requirements tend to pose constraints to the exports of leather and footwear in developing countries (e.g. Brazil) in the short-run, but in the mid to long run their negative effects tend to be attenuated and become beneficial to the productive chain as a whole. In this regard, the research question pursued was the following: what are the impacts and challenges posed by current international standards, regulations and market requirements that can be seen as technical barriers to trade of leather and footwear produced in developing countries such as Brazil?

Based on this question, two following objectives were designed to guide the research: (i) to analyze and discuss to what extent the international standards and regulations, and technical requirements can effectively be considered technical barriers to trade of leather and footwear; and (ii) to assess qualitatively the impacts and challenges posed by these standards, regulations, and technical requirements to the Brazilian industry in the short, mid and the long-run.

The research methodology to carry out this study consisted of (i) literature review including documents, websites, papers, dissertations and reports; (ii) interviews with Brazilian professionals from private companies, universities and research institutions, and (iii) a brainwriting session with experts in the leather and footwear industry. The interviews were supported by open-ended questionnaires and the brainwriting session was carried out with fifteen experts from the industry, academia and research institutions.

\section{Literature review}

Technical barriers to trade have deserved attention in the areas of economic policy, industrial and foreign trade, and environmental studies. WTO defines technical barriers as trade barriers arising from the use of standards or technical regulations that are not transparent or not based on internationally accepted standards. These barriers can also result from the adoption of conformity assessment procedures that are not transparent and/or are too expensive to exporting companies and countries. In addition, they can derive from excessively stringent inspections resulting either from the standards set by the signatory countries or the harmonization of standards worldwide (Instituto Nacional de Metrologia, Normalização e Qualidade Industrial, 2005).

Prazeres (2003) argues that technical barriers are restrictions on the flow of international trade based on requirements related to the characteristics of the goods to be imported. These requirements can either refer to the content of the product or the tests showing that a product meets the relevant specifications imposed by the importer.

According to Perina; Machado \& Miranda (2003), the technical standard is characterized as a non-tariff barrier when there is: 
a. An imposition of cultural and technological standards incompatible with the exporting country, implying major changes in the production process, increasing costs without technical justification;

b. Discrimination against imported products;

c. Discrimination of input use, especially for agricultural products under the unproven allegation of damage to health and the environment;

d. Lack of clear disclosure about the technical requirements.

According to the Brazilian Ministry of Development, Industry and Foreign Trade, the growing complexity of international relations coupled with the evolution of society have led to the establishment of environmental and social requirements that traditionally had not been covered in trade negotiations (Ministério do Desenvolvimento, Indústria e Comércio Exterior, 2002). According to Castro et al. (2003), it is difficult for negotiators of international agreements to differentiate between those measures required by importers that are really necessary and legitimate for environmental protection required from those that have a protectionist character. In the short run, this leads to an increase in the costs of production and price of the product affecting its competitiveness in the exporting market, as the adaptation to new requirements is necessary.

Procópio Filho (1994) calls this eco-protectionism, an assignment to the use of environmental policies that restrict international trade. In order to deal with this challenge, at the commencement of the Doha Development Round in November 2001, a group was formed to analyze the insertion of multilateral environmental agreements in trade negotiations.

It is important to remark that establishing objective criteria for environmental, social and sustainability issues is a hard task due to a) scientific uncertainties regarding quantitative issues; b) lack of acceptable short-term or long-range risk levels for each of these issues; and c) lack of a general consensus on how to effectively pursue sustainability when the international trade is the subject matter.

The Brazilian Ministry of Development, Industry and Foreign Trade points out that the technical regulations are promulgated by the government. Such regulations impose technical requirements that are mandatory for all products they encompass or establish rules for the corresponding conformity assessment procedures applicable in these cases (Ministério do Desenvolvimento, Indústria e Comércio Exterior, 2002).

However, there are some barriers that are not based on measures established by the State. In this case, it is the market that sets them up either by practice or tradition. In specific cases, they can also be established by "technical habits", technical requirements, or even by reasons specified by clients regarding the quality of the demanded product or service. Thus, these requirements may end up as being technical barriers, especially when they differ from those valid for countries to which exports of goods and services will be made.

Garrido (2004) considers that the legitimacy of the barriers in these cases should not be questioned because any importer may establish requirements as it deems necessary to meet its needs. This author argues that technical barriers, broadly speaking, have always existed, 
although its importance has increased due to the continuous decrease in tariffs in recent years. According to him, many of these barriers were not noticed before because of the existence of high tariffs which made them somewhat invisible. He also adds that from the point of view of competitiveness of the countries involved, as most markets require different technical requirements for the same products or services, this multiplicity of demands results in rising costs posing serious difficulties for them. Prazeres (2003) considers that the developing countries tend to be the losers in this case because of the impacts of the requirements on exports.

\section{An overview of the leather and footwear industry}

For the purpose of this chapter, the leather and footwear industry can be divided into two major areas: leather processing and leather products manufacturing. However, it has important interfaces with other sectors, such as chemistry, footwear components production, machines and tooling, packaging, among others (Instituto de Pesquisas Tecnológicas, 2006).

In recent decades the spatial distribution of this industry has been changing worldwide and also at the regional level. Internationalization of production and industrial relocation towards less developed countries, regions and states with less stringent environmental regulations and cheaper labor are among the major factors responsible for this change. In this new geographical scenario, Eastern European countries have increased their wet-blue leather production (Santos et al., 2002), and China and India have turned into the biggest leather and footwear suppliers. Brazil still remains as an important footwear producer and exporter due to its comparative advantages of having the biggest cattle herd of the world. Other than being an important leather exporter, Brazil has also exported qualified labor to China and India (Santos et al., 2002). USA, Germany and other European countries are major leather importers (Saravanabhavan, 2005) turning part of the imports into high quality finished leather and footwear for export (Instituto de Pesquisas Tecnológicas, 2006). Italy is known to be benchmark for high-quality finished leather, and uses this to keep a position in the fashion and design market (Santos et al 2002).

In the early 1990s India was the eighth largest footwear producer (Desai, 1995), but its performance in the international market has been changing rapidly through the removal of restrictions to the international trade. Although its economy is still relatively protected, government has been cutting tariffs and non-tariff barriers, phasing out quantitative restrictions and removing other limitations to foreign investments. Progressive liberalization has produced remarkable results (World Bank, 2008) pointing out that the country has the potential to become an important player in the international market in several industrial areas, including footwear.

The role of Brazil as an important leather exporter started in the 1990s. However, it has historically exported mainly low-value contents leather, in the wet-blue stage. Only recently the finished product exports surpassed $50 \%$ of the total amount as shown in Figure 1. 


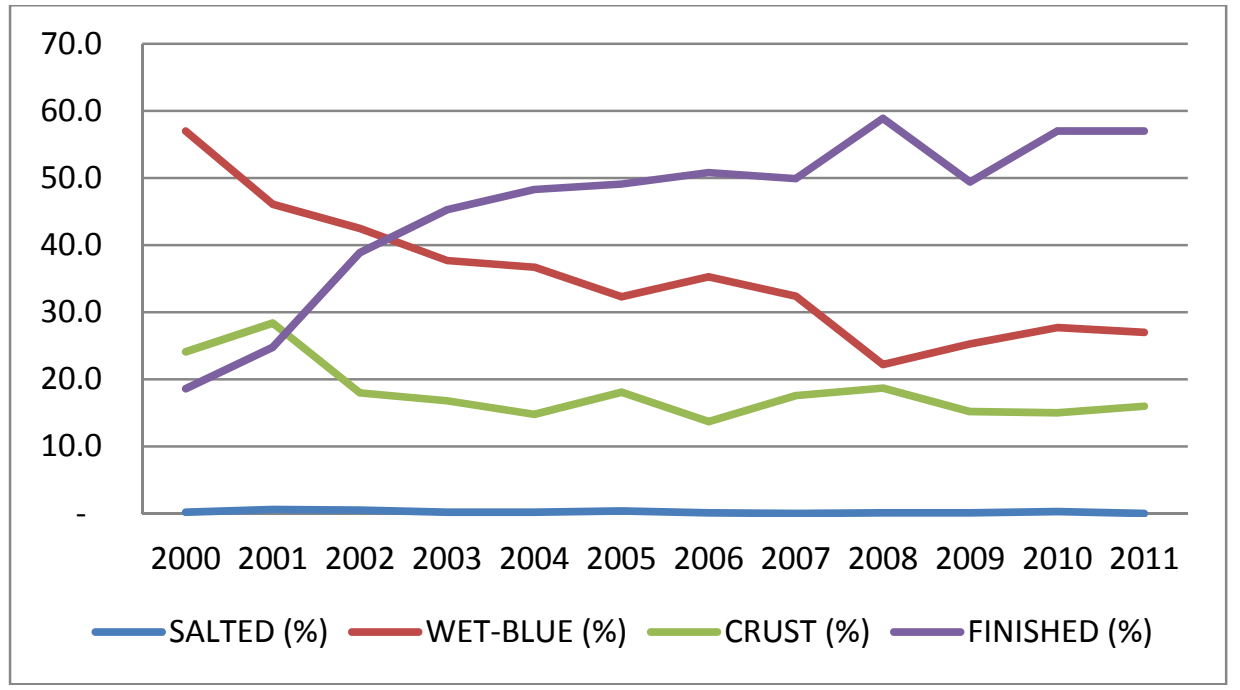

Figure 1. Brazilian exports by leather type

Source: Agência Brasileira de Promoção de Exportação e Investimentos (2012)

According to Fernandes (2004), leather and footwear supply chain is key to the Brazilian economy. By moving around US\$ 21 billion annually, from which US\$ 3.5 billion have been exporting of leather and footwear in 2010, it can significantly affect internal and external markets, and generate many job positions.

Brazil also moves intense trade in the footwear market. It is a traditional producer and exporter of leather shoes, and now also plays a role in importing sports footwear from Asian countries. Table 1 and figures 2, 3 and 4 summarize key information on this.

\begin{tabular}{|c|c|c|c|c|c|c|}
\hline \multicolumn{2}{|c|}{ Description } & 2008 & 2009 & 2010 & $\% 2010 / 09$ & $\% 2010 / 08$ \\
\hline \multirow[b]{2}{*}{ Production } & Pairs (millions) & 816.0 & 813.6 & 893.9 & $9.9 \%$ & $9.6 \%$ \\
\hline & $\begin{array}{c}\text { Value (US\$ } \\
\text { millions) }\end{array}$ & $10,233.2$ & $9,454.6$ & $\begin{array}{c}12,34 \\
0.4\end{array}$ & $30.5 \%$ & $20.6 \%$ \\
\hline \multirow[b]{2}{*}{ Exportation } & Pairs (millions) & 165.8 & 126.6 & 143.0 & $12.9 \%$ & $-13.8 \%$ \\
\hline & $\begin{array}{l}\text { Value (US\$ } \\
\text { millions) }\end{array}$ & $1,881.3$ & $1,360.0$ & $\begin{array}{c}1,487 . \\
0\end{array}$ & $9.3 \%$ & $-21.0 \%$ \\
\hline \multirow[b]{2}{*}{ Importation } & Pairs (millions) & 39.3 & 30.4 & 28.7 & $-5.5 \%$ & $-27.1 \%$ \\
\hline & $\begin{array}{c}\text { Value (US\$ } \\
\text { millions) }\end{array}$ & 307.5 & 296.5 & 304.6 & $2.7 \%$ & $-0.9 \%$ \\
\hline
\end{tabular}

Source: Associação Brasileira das Indústrias de Calçados (2011)

Table 1. Brazilian footwear industry in numbers 
Technical Barriers to Trade of Leather and Footwear: Impacts and Challenges Posed by International Standards, Regulations and Market Requirements in Brazil

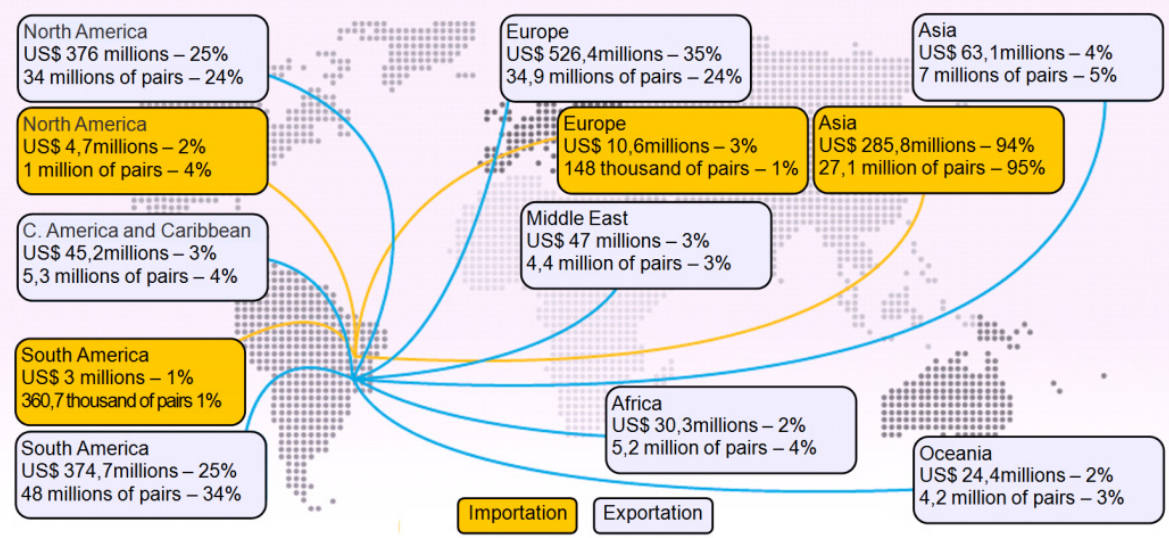

Source: Associação Brasileira das Indústrias de Calçados (2011)

Figure 2. Brazilian footwear imports and exports (2010)

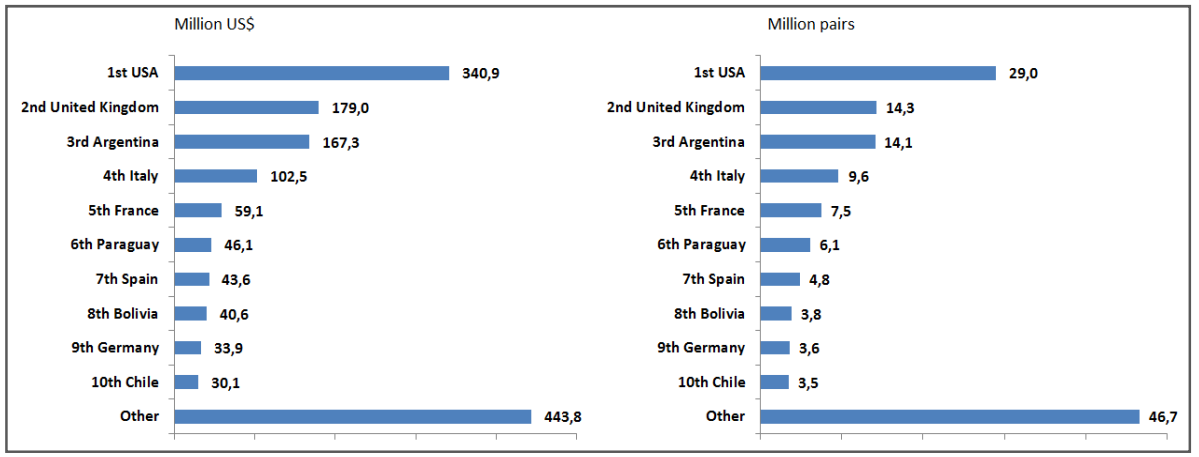

Source: Associação Brasileira das Indústrias de Calçados (2011)

Figure 3. Brazilian shoes industry - exports by destination (2010)

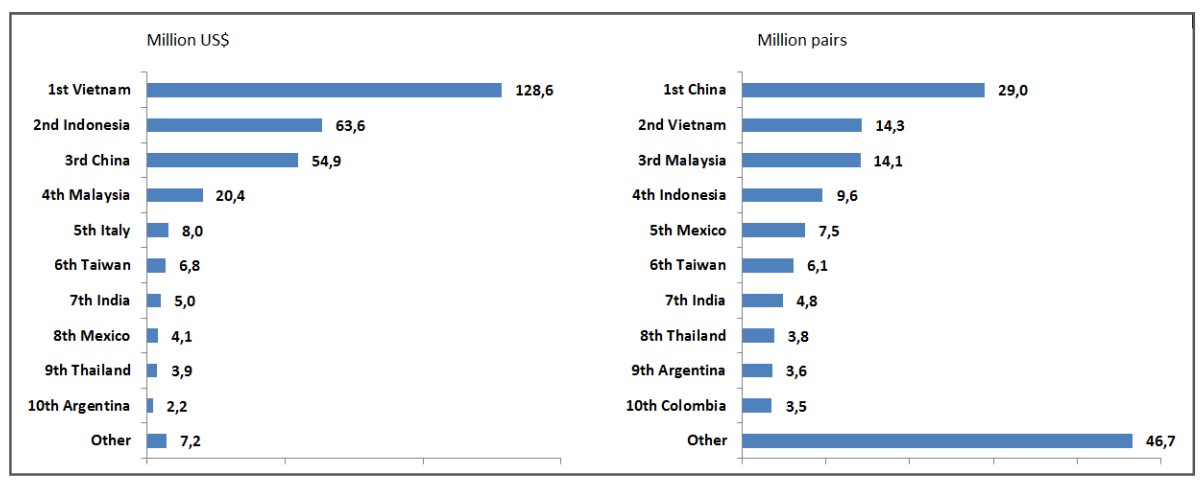

Source: Associação Brasileira das Indústrias de Calçados (2011)

Figure 4. Brazilian shoes industry - imports by origin (2010) 
Originally leather industry in Brazil was located mainly in both Southern and Southeastern regions. However, the cattle have significantly grown in the Central-west region, where companies that produce meat are also in the wet-blue leather business. Their location is due to cost reduction opportunities (Santos et al., 2002). Gaspar (2006) argues that this change is a consequence of unfavorable currency taxes, closure of some markets and more intense competition. Less stringent environmental requirements and lower labor costs have also been reasons for the moves.

Footwear production went through similar migration moves countrywide. According to Rosa and Corrêa (2006), this started in the early 1990s. At that time production conditions and competition changed and the companies moved from the South and Southeast states to Northeast, looking for cheaper manpower, local government incentives and to a better geographical position to export. These advantages surpassed the complete industrial integration in the traditional Southern production centers, e.g. Sinos River Valley (Gorini \& Siqueira, 2002).

In Brazil, most of the leather processing industries and leather artifacts industry are small and medium sized companies that are still owned and managed by families (Campos, 2006). Small enterprises focus on internal market, and typically use processes with low level of automation ("artisans") and have no or scarce knowledge of the requirements and limits for the use of certain substances and processes in the external market. Only a few medium companies are prepared for exports.

These companies are facing pressures due to competition coming from foreign countries where an ongoing fast technological development is taking place (e.g. China and India) and also from other regions in Brazil where local government are providing incentives for new companies.

\subsection{Leather processing and environmental issues}

Leather processing plays a key role in several countries all over the world. Food and Agriculture Organization (2011) estimates that 1.67 billion of square meters of leather are produced annually worldwide. The complete processing for the leather production, from raw skins up to completely finished leather can be summarized as follows:

a. Cleaning and preservation after abatement: basic cleaning and care to preserve skin/hides to processing;

b. Pre-tanning: elimination of certain parts such as meat, fat and hairs;

c. Tanning: chemical treatment to make leather stable and non-putrescible; and

d. Finishing: operations to give leather specific features such as color, softness, waterproofing, among others.

Approximately $90 \%$ of pollution loads comes from pre-tanning and tanning. Tanneries are generally under pressure to minimize final pollution loads (Saravanabhavan et al., 2005; Ramasami et al., 1999). Box 1 summarizes the main environmental issues of leather processing. 


\begin{tabular}{ll}
\hline $\begin{array}{l}\text { Environmental } \\
\text { aspects }\end{array}$ & Features \\
\hline $\begin{array}{l}\text { Use of azo dyes } \\
\text { Use of }\end{array}$ & Chemical gives color to leather \\
formaldehyde & Used for tanning
\end{tabular}
Hexavalent chromium

\begin{tabular}{|c|c|}
\hline Solid Waste & $\begin{array}{l}\text { Significant amount of trimmings, } \\
\text { degraded hide, lime sludge, flesh } \\
\text { and hair from beamhouse } \\
\text { processes. Depending on the } \\
\text { stage can contain Hexavalent } \\
\text { chromium Production wastes } \\
\text { containing hexavalent chromium } \\
\text { can be characterized as hazardou } \\
\text { waste according to Brazilian } \\
\text { regulations (Sousa, 2006) }\end{array}$ \\
\hline Effluents & $\begin{array}{l}\text { Off-neutral } \mathrm{pH} \text {, lime, sulfides, } \\
\text { hexavalent chromium (Contador } \\
\text { Junior, 2004) }\end{array}$ \\
\hline & Organic matter \\
\hline & $\begin{array}{l}\text { Salinity (Contador Junior, 2004; } \\
\text { Sousa, 2006) }\end{array}$ \\
\hline \multirow{2}{*}{$\begin{array}{l}\text { Air emissions of } \\
\text { toxic or odor } \\
\text { substances }\end{array}$} & Ammonia \\
\hline & Hydrogen sulplhide \\
\hline \multicolumn{2}{|l|}{$\begin{array}{l}\text { Air emissions of } \\
\text { fuels (Contador } \\
\text { Junior, 2004) }\end{array}$} \\
\hline $\begin{array}{l}\text { Wastewater } \\
\text { treatment Sludge }\end{array}$ & $\begin{array}{l}\text { Coming from tanning and } \\
\text { chromium-treatment (Contador } \\
\text { Junior, 2004) }\end{array}$ \\
\hline
\end{tabular}
risk of deseases such as neural and cancer in some cases, and can be cumulative in the live organisms.

\section{Comments}

Tanning material, hardener and fastness (Wolf e Schuck, 2003)

Substitutes such as $\mathrm{Zr}, \mathrm{Al}$, Ti and

vegetable tannins are not effective for all applications Hoinacki, Moreira \& Kiefer (1994); Sousa (2006)

Risks of spontaneous oxidization of CrIII to $\mathrm{CrVI}$ in the open-air dumps as well as the possible risks of wearing bad quality shoes, in which the chromium content is not controlled (Kolomaznika, 2008)

Can represent $70 \%$ in weight of original hides (World Bank, 1999)

Azo dyes are also present

Mainly proteins (Sousa, 2006)

Released during deliming (World Bank, 1999)

Released during mixing of dehairing and pickling wastewater (World Bank, 1999)

Chromium levels in untreated tannery wastewater are typically $100-400 \mathrm{mg} / \mathrm{L}$, while the international standard for chromium bearing discharges is less than 2 mg/L (World Bank 1999; Buljan 1996; Saravanabhavan et al., 2005)

Table 2. Major environmental issues of leather processing 
Today, the main environmental concerns of this industry focus on the disposal of the large volumes of potentially hazardous wastes. Due to their degree of risks to human beings they should be disposed of in landfills, recycled or treated via an environmentally sound process. However, it is remarkable the amount of small tanneries in the interior of Brazil that are operating with low technological conditions and far from the environmental agency's eyes. Although in theory the existing environmental regulations are able to deal with them, it is almost impossible to assure that their waste disposal is always carried out following adequate technical procedures. The main wastes are chips, shreds, crumbs, sander dust and mud of both chromium and re-tanning.

As for wastewater, concerns focus on the large volumes with high salt concentration (sulfides, sulfates, chlorides) and high toxicity, especially due to the mineral chromium tanning and various azo dyes from the dyeing. Requirements of the European directive on these dyes from February 24, 1994 applicable to articles of clothing and artifacts of leather producers deserve the special attention of labs providing chemical analysis for the leather and footwear industry at the country level.

On one hand, tanning industry can be seen as an important way to deal with wastes coming from the meat industry. On the other side, data provided by Kolomaznika (2008) show that it is both a low eco-efficient and a serious pollutant industry, as follows:

a. Final leather product yield is $200 \mathrm{~kg} /$ ton of raw hides;

b. Waste generation is around $250 \mathrm{~kg}$ of non-tanned solid waste and $200 \mathrm{~kg}$ of tanned waste containing $3 \mathrm{~kg}$ of chromium per ton of raw hide;

c. Wastewater generation is around $50 \mathrm{~m} 3$ / ton of raw hide, containing approximately 5 $\mathrm{kg}$ of chromium;

d. More than $60 \%$ of originally used chromium is lost in the wastes and wastewater.

Additionally, it is estimated that each footwear production leads to the generation of $220 \mathrm{~g}$ of total wastes. According to Centro Tecnológico do Couro (as cited in Companhia de Tecnologia Ambiental de São Paulo, 2011) the generation of wastewater in Brazil is around 25-30 $\mathrm{m} 3 /$ ton of salted skin. In order to facing environmental, regulations and productivity challenges, the leather industry is internalizing a number of technological changes in its production processes, as follows:

a. Use of enzymes in the tanning process as substitutes of chemicals (Gutterres, 2005);

b. Use of enzymes to treat waste and wastewater (Saravanabhavan et al., 2005);

c. Minimization of use of hexavalent chromium, azo dyes and formaldehyde due to regulations in several countries, particularly in Europe.

Considering that in several countries the leather industry is still at lower technological stages, many companies will have to invest in modernization, including machining, layouts, wastewater treatment systems, automation and process controls (Gutterres, 2005). 


\subsection{Environmental management in the leather industry}

International pressures coming from technical barriers to trade are pushing footwear manufacturers that are involved in exports to follow the requirements to reduce the level of hazardous substances in these products. Backward in the supply chain, these manufacturers push the leather processors that ultimately push the tanneries in this regard. As a response, only the most organized tanneries tend to effectively reduce the use of chemicals that pose risks to human health. A number of them are not capitalized enough to meet all the requirements. This tends to create two different industries, just like two different worlds: the world of the companies that export, and the world of the companies that only meet the demand of the domestic market. In general, the latter is small sized ones that use traditional technology, this way barely meeting the requirements of the local regulations or being completely invisible to environmental agencies.

CETESB, the environmental agency of Sao Paulo State, coordinates an environmental chamber with the participation of leather companies to discuss environmental issues. A recent agreement of this chamber resulted in a procedure for an environmentally sound destination of powder and trimming wastes containing hexavalent chromium (Companhia de Tecnologia Ambiental, 2011).

Currently, the environmental management practices are key to companies that intend to achieve International Standardization Organization - ISO 14001 management systems certification. Such practices are also important to improve employees' awareness, enhance productivity, reduce loss, minimize accidents, and improve the organization as a whole.

According to International Standardization Organization (2011), there was 440 plants in the leather and leather products sector that were ISO 14001 certified in 2010. Similar statistics were not found in Brazil.

Implementation of environmental management actions in the leather and footwear sector is important based upon a series of issues that the sector faces, such as presence of heavy metals in effluents, air emissions from glues and solvents that can have negative impacts on workers in the internal environment. Among other relevant issues are the financial resources that have to be spent on water and electricity, risks that are associated with chemicals handling and storage, and odor that is generated by tanning.

\subsection{Issues involving leather products}

In the case of finished footwear, the European ecological label scheme establishes a maximum of $150 \mathrm{ppm}$ of formaldehyde in the leather. Equivalent Japanese standard limits formaldehyde to 112 ppm (Glasspool, 2006).

Wolf e Schuck (2003) reported an increase in positive results for CrVI in the analysis. According to them this increase can be related to both lack of previous attention given by leather producers to the restrictions and the increase in the chemical analysis demanded by 
importing countries. They emphasized that excessively high $\mathrm{pH}$, ammonia and use of fishoil based greasing agents should be avoided in tanning to minimize $\mathrm{CrVI}$ presence.

Even considering that presently several tanneries are not intentionally using CrVI compound, there has been a few cases in which a high concentration of this element was found in their exported leather products to European and Asian countries (Sousa 2006). In this regard, Dexheimer (2006) states that this CrVI can result from a cumulative process derived from one or more processing steps or as impurities of chemicals used in the "wet" stages of tanning, re-tanning and finishing.

\section{International standards, regulations and market requirements on leather and footwear}

This section covers the major technical regulations and market requirements given special attention to the EC directives, as follows: 76/769/EEC that sets up limits to market insertion of leather products and also to the use of hazardous chemical substances and preparations; 2002/231/EEC that refers to ecological criteria for attribution of community ecological labels to shoes; and 2004/21/EC that sets up limits to market insertion of leather products and also to the use of azo dye.

The EC directives dealing with restrictive substances in products are imposed by the EU technical regulations whose compliance is mandatory. These directives give priority to the safety of the user in respect of any products or chemicals in products as well as with respect to physical well-being.

The European legislation, which tends to establish general standards for global mandatory restrictions, restricts the use of certain chemicals and these should be in accordance with the goods traded within the EU. Most restrictions are amendments to the directive 76/769/EEC which governs individually all aspects of production, sale and use of chemicals.

The directive 76/769/EEC was adopted on July 27, 1976 aimed at limiting the concentration of hazardous substances to human health and the environment. Over the years, it had twenty-nine amendments and adaptations. Its last revision occurred on January 18, 2006 and was published as directive 2005/90/EC.

A very significant directive for the leather and footwear industry was approved by Decision of the Commission of European Communities and published on March 18, 2002. This policy established revised ecological criteria for the award of community eco-label to footwear. It applies to footwear and its production process, including processing of leather, as considered in the life cycle approach. The main criteria considered in the policy and standards aim to:

a. Limiting the levels of toxic waste;

b. Limiting emissions of volatile organic compounds (VOC);

c. Promoting a more durable product. 
The criteria for obtaining the eco-label are:

a. The concentration of toxic substances in the final product, especially the hexavalent chromium content that must not exceed $10 \mathrm{mg} / \mathrm{kg}$; in addition, heavy metals such as arsenic, cadmium, and lead are not expected to be detected at all;

b. The concentration of free and partially hydrolysable formaldehyde expected in the textile components of the footwear must not exceed $75 \mathrm{ppm}$; the amount of these compounds present in the leather components must not also exceed $150 \mathrm{ppm}$;

c. Emissions from the footwear manufacture (priority given to wastewater), which must have after due treatment in individual or collective stations, a chemical oxygen demand (COD) reduction of at least $85 \%$ related to raw wastewater and total chromium concentration less than 5 ppm;

d. Footwear must not contain harmful substances such as pentachlorophenol (PCP), tetrachlorophenol (TCP) and their salts and esters. The threshold values are $0.05 \mathrm{ppm}$ for textile components and 5.0 ppm for leather components;

e. Azo dyes that can be decomposed into a series of aromatic amines may not be used; tolerable limits are 30 ppm for textiles and leather;

f. The rubber used in footwear manufacturing must not contain a series of $\mathrm{N}$ nitrosamines;

g. Chloroalkanes (C10-C13) must not be used in components of leather, textile or rubber;

h. Volatile organic compounds (VOC) must not be used in the assembly;

i. Footwear shall not contain polyvinyl chloride (PVC), except when this compound is recycled in soles and is not employed in preparing some phthalates;

j. Providing information, on a voluntary basis, on energy consumption per pair of shoes;

k. Footwear shall not contain electric and electronic components;

1. Final packaging of footwear must contain at least $80 \%$ recycled material, statement of use, and information making it clear that a shoe was manufactured within the standards established in the directive;

m. Adoption of environmental management systems such as ISO 14001 is not mandatory but recommended (Comissão das Comunidades Europeias, 2002).

An example is the New Zealand criteria for ecolabelling of leather products. The criteria establish a limit of $3 \mathrm{ppm}$ of $\mathrm{CrVI}$ in the leather products and a maximum of $1 \mathrm{ppm}$ of $\mathrm{CrVI}$ in the treated effluent (The New Zealand Eco-labeling Trust, 2006). This is more stringent than the European criteria and shows that the lack of consensus in risk perception can lead to different technical criteria and therefore to technical barriers.

The European directive 2004/21/EC, established in January 1, 2005 is another policy that affects the leather and footwear industry. Its purpose is to protect the health of the population, limiting the insertion of finished goods in the European market of textile and/or leather in any parts dyed with azo dyes; the major concern is that a person under a prolonged exposure to these substances may become susceptible to cancer (Comissão das Comunidades Europeias, 2002). 
According to this policy, by reductive cleavage of one or more azo groups (-N=N-), the dyes may release one or more of aromatic amines, detectable at concentrations above $30 \mathrm{ppm}$ as the test methods set forth. This is a significant topic supported by the following information supplied by Clariant Brazil (2006):

a. $90-95 \%$ of leather produced worldwide is dyed with azo dyes;

b. $50-60 \%$ of all produced leather is dyed in black;

c. There is a high demand for dyed through leather;

d. There is an increasing demand for strong re-tanned and strongly dyed leather for shoes manufacturing;

e. There has been an increase in the production of leather upholstery, especially in Brazil;

f. Continuous growth in solidity requirements and internationally normalized resistance;

g. Enhancement of the human ecology concept, restricting the use of substances classified as hazardous to the consumers' health and welfare.

According to Inmetro - Instituto Nacional de Metrologia, Normalização e Qualidade Industrial (2005), monitoring for compliance of products with the requirements of the referred directive is carried out by sampling of products found in the consumer market and not at the borders. The Brazilian Association of the Textile and Clothing (ABIT) concerned with possible harm to Brazilian exporters, asked the companies producing dyes and pigments countrywide a statement of compliance to the directive $2004 / 21$ as it concerns to manufacturing and marketing of dyes for textiles and leather.

Currently labeling is also a topic addressed in technical rules notified by the countries at the WTO, especially as a justification for imposing technical requirements. According to Castro, Castillo, and Miranda (2004), the eco-labels are seals that are intended to inform the consumer about some characteristics of the product. Environmental labels are often known as Green Seal, Environmental Seal or Eco-label. Presently there are many different labeling programs that can be classified into two groups as follows: those adopted and implemented by the manufacturer of the products, and those named third party labeling, conducted by an independent manufacturer.

The European label was created in 1992 by decision of the European Parliament, implemented by the EU Council in the following years, and finally named Ecolabel. It is voluntary, but required for imported products, taking into account the life cycle of each product. This is the first seal to be adopted both regionally and transnationally (Ecoetiqueta Europea para el Calzado, 2006).

The European Eco-label distinguishes the products of high standards of performance and environmental quality. Every product awarded the European Eco-label is subject to rigorous environmental testing by independent organisms. To obtain the seal the following measures should be adopted:

i. Large part of manufactured packaging has to come from recycled material;

ii. Water consumption during production has to be limited;

iii. The amount of chemical residues has to be limited; 
iv. Non-recyclable plastics are prohibited;

v. Use of certain categories of dangerous chemicals is also prohibited;

In addition to all these measures, the footwear must comply with the flexural strength, tear strength and abrasion as well as the accession of the sole to the top. Other countries also have created regulations on leather and footwear that sometimes can be seen as technical barriers to trade. In the USA, for instance, concerns seem to be more focused on physical and mechanical properties of materials used in soles and heels than properly on chemical hazardous substances. Schneider (2006) argues the American rules' flexibility as compared to the EU ones is related to the USA dependence on the China's footwear production. According to him, being the USA the largest consumer of footwear worldwide, it would not be wise to counter an industrial power like China, which provides the basic day to day articles to that country, especially for lower income people.

Japan requirements on leather and footwear are similar to the imposed by The European Directives. This happens because the exports are made via European trading companies that receive the shipments in Rotterdam sending them to Japan afterwards.

Due to the increasing awareness of society, corporations such as Adidas, Nike, Clarks, Reebok and Ralph Lauren are also imposing stringent technical requirements for both suppliers of raw materials (leather, plastics, adhesives, glues etc.) and finished products (artifacts in leather and textiles) so as to ensure end-user safety and environmental protection. This also happens with footwear that has been sent to popular mega stores such as Wal-Mart in the USA and Bic in Germany. These demands on imported footwear are forcing producers in developing countries to attend these requirements. Since trading companies export to a number of countries which adopt different rules, tanneries in the domestic market are being forced to meet most of these requirements.

The most important restrictions focus on heavy metals and azo dye on input suppliers or finished products. In addition, some physical and mechanical requirements usually related to soles and heels are also made by these companies.

\section{Impacts and challenges posed by international directives and regulations}

In the short-run, specialists consider that the high costs of chemical analysis demanded by the EC directives to adjust products and production to the requirements of the foreign market as a negative impact. Small tanneries are the ones having their competitiveness affected as a result of this economic impact on leather processing. On the other hand, some specialists also mentioned that adoption of clean technology, labor qualification, and selection of better qualified raw material suppliers are the positive impacts of the EC directives in the referred sector. This way, the assessment of the impacts depends on the perspective of analysis and also in the time horizon taken into consideration.

Girolla (2006) states that the certification of the leather and footwear supply chain is something to be expected in the coming years as the market and regulatory pressures for 
cleaner production grows up. He emphasizes that the whole process has to be supported by labs that need to be recognized, certified or accredited by importing countries. In this regard, it is important to highlight the high costs of maintenance of a lab quality system as required to the Brazilian Technical Norms known as ABNT NBR 17025 series.

A positive impact of the EC directive mentioned by Schneider (2006) is the periodic visit of international auditors in the Rockport office at Campo Bom - RS to assess whether industries manufacturing footwear is adequately following the international rules and technical requirements on both environmental and social issues. As for social issues the major concerns focus on child labor and the working conditions in the footwear factories.

Another positive impact of the EC directives is that initiatives similar to the ecological footwear, originally developed in Europe, are being spread around the world. This type of footwear is customized and manufactured with biodegradable materials.

In Brazil, the Footwear Division of the National Service of Industrial Learning (Senai of Novo Hamburgo - RS has developed an ecological footwear with leather tanned with organic products and other non-hazardous substances. In addition, the soles were made with natural rubber, adhesives prepared without organic solvents, foams manufactured without toxic, flammable or corrosive substances, and packaging made of recycled material. Also the manufacturing process resulted in a reduction of water consumption and waste generation (Girolla, 2006).

According to the interviewed specialists, the major challenges posed by the EC directives that need to be overcome by developing countries in the mid to long-run are the following:

a. Development of new tanning processes and products, and definition of productive strategies as to prevent the formation of $\mathrm{CrVI}$ during the tanning process.

b. Lab improvements as it concerns to infrastructure and methodologies, metrological updates, accreditation, and organizations of inter-lab programs.

c. At scale production of ecological footwear will depend on changes of current production processes as to allow the introduction of new tanning materials less harmful to the environment than the traditional ones.

d. Problems related to sample heterogeneity and differences in assay results are expected to be subject of future insurance (legal barriers) to be covered by the leather and footwear industry.

\section{Discussion of major findings}

At the global level, the most common technical barriers on leather and footwear are related to rules and regulations posed by economic blocks (e.g. European Community) or developed countries such as Japan, Korea, USA and Canada. The EC directives are the major example as they set up limits to toxic wastes in leather and footwear aiming to promote more durable products based on international standards. Since these directives define the methods or analytical procedures for conformity assessment, in some aspects they have been considered technical barriers to trade; this is the case when the exporting countries are 
not able to meet the required standards due to technological limitations in the production processes or in the lab infrastructure.

Differences in fixing specific limits for hazardous substances as well uncertainties regarding the presence of some of them in leather can also be subject of controversy as it concerns to technical barriers. For instance, while German regulation sets $3 \mathrm{ppm}$ as the tolerable limit for CrVI, the European legislation sets it at $10 \mathrm{ppm}$. It is worth mentioning, however, that both methods are debatable, since it has been argued that a formation and subsequent detection of CrVI could occur when the chemical analysis is being performed. In this context, one of the major concerns of the leading leather and footwear producing countries today is that these limits and the required conformity assessment tests do not result in unjustified discrimination or arbitrary restrictions to international trade of these products.

As to preventing problems related to CrVI, both automobile and furniture companies all over the world are increasingly demanding mineral tanned (titanium-based) leather.

According to some interviewed specialists, the adequacy of this sector to the new market conditions will require a considerable amount of investment and also a new management perspective. Some tanneries in Southern Brazil are already adapting their production processes to the ISO 14.001 standards.

Also in response to the global market pressures, some multinationals (e.g. Colorobbia, Clariant) have already developed specific lines of natural dyes to meet the growing demand for products with lower content of potentially harmful chemical substances (Souza, 2006).

In Brazil and other Latin American countries there is no specific legislation limiting the level of toxic waste in leather and footwear. Since technical barriers affecting this industry are growing up in importance worldwide, some concerns expressed in the international directives are expected to be internalized in the Brazilian environmental regulation in the coming years.

Considering also that most of the rules and regulations that impose restrictions on the marketing of hides and artifacts requires proof of compliance (e.g. via conformity assessment, including certification), targeted actions for lab training to issue certificates and to participate in certification programs countrywide should be part of a specific public policy in Brazil. One important step in this direction is to make the Brazilian NBR norms compatible to the European ISO norms. The expansion of interlab programs nationwide is also becoming more evident to attend chemical analysis and mechanical tests demanded by the leather and footwear sector and others.

\section{Conclusions}

The final remarks are focused on what extent the analyzed technical standards and regulations (including the EC directives) and the market requirements that can be considered technical barriers to trade, and also on some suggestions to face them. Two 
aspects were considered relevant in this regard: (i) the time frame between the promulgation of an international regulation and its applications in the leather and footwear industries worldwide, and (ii) the resulting impacts of this regulation at both the industry and lab infrastructure levels in Brazil. For instance, the EC directives can be considered informal technical barriers in the short-run (right after promulgation by EC and imposed on developing countries exporting to Europe) as they directly affect the industries' production costs and competitiveness. Although WTO recognizes the right of the developing countries to have enough time to adequate their industries to meet the requirements of these regulations, EU countries tend not to pay attention to this right after the directives promulgation. EC directives only become formal technical barriers to trade by the time they are recognized by the WTO as accepted technical regulations. Since the technical requirements posed by corporations are not accepted as technical regulation by the WTO, they are considered informal technical barriers to trade.

However, it was realized that there is a controversy among specialist on what is a form (legitimate) or informal (illegitimate) technical barrier to trade. While some consider that a technical requirement can be seen as a technical barrier only if it is demanded by a country, others argue that they can also be required by a corporation, especially if it can influence the global market of the leather and footwear, for instance. In the latter, it has been argued that in some cases corporations are adopting different specifications for a unique type of product, for instance, only as a business strategy to acquire products at relatively lower prices. One could argue that it is a discriminatory procedure and, this way, the corporation would be introducing a technical barrier to trade.

Another important aspect to be pointed out is that the introduction of new technologies in the developed countries tends to be less difficult than in developing ones creating a technological asymmetry that can result in technical barriers to trade. This happens because even when the rules and technical requirements are formal, the developing countries face difficulties to follow them. In this case, it should be remembered that the GATT recognizes the right of developing countries to introduce technical standards according to their level of development and have a longer time to adapt to the requirements of international standards.

A service named "Alerta Exportador" provided by Inmetro (Brazilian focal point), has helped domestic small and medium size exporting companies to identify and inform technical barriers.

Also it is possible to conclude that the international market for leather and footwear has forced environmental improvements in the Brazilian supply chain of leather and footwear. However, oeHoconsidering that the stage of technological development of tanneries is higher in the southern states than in the ones located in the northern states, it cannot be expected that all the country's production is environmentally sound.

Some specialist argument that these technical barriers affect the exports of the developing countries in the short-run, but in the mid to the long-run they have a positive effect both in 
the qualification of all firms in the footwear and leather productive chain and in the competitiveness of the exporting ones. However, it is not easy to perform a cost-benefit balance on that or, the other way, to say who gained or who lost in this two side polemic issue.

As it refers to laboratory infrastructure, one can say that several Brazilian labs need to improve their infrastructure to attend the demand for chemical analyses on restrictive substances required by the EC directives. The ones that are better qualified to attend this demand are located in both Rio Grande do Sul e Sao Paulo states, but they still need to be both recognized and accredited abroad.

A strategy previously adopted by both India and China that could be also adopted in Brazil is the attraction of labs that perform analyzes and tests that are recognized worldwide. In addition, our country could also make the accreditation of national labs by Inmetro and also by international organizations, such as Satra, Bureau Veritas and others. Finally, we suggest that the Brazilian Ministry of Development, Industry and Foreign Trade provide funds for a study to quantify both the positive and negative impacts of technical barriers in the leather and footwear sector. The results of this study can provide relevant data and information to support a public policy to help tanneries, labs and leather using companies to overcome some negative impacts and also to improve exports. This policy could make a difference considering that the market for leather and footwear is becoming even more competitive with the emergence of China and India as major exporters.

\section{Author details}

Mauro Silva Ruiz and Cláudia Echevenguá Teixeira

Nove de Julho University - Uninove, Brazil

Institute for Technological Research of Sao Paulo State - IP, Brazil

Alexandre de Oliveira e Aguiar and Gustavo Silveira Graudenz

Nove de Julho University - Uninove, Brazil

Pedro Luiz Cortez

Nove de Julho University - Uninove, Brazil

University of Sao Paulo-USP, Brazil

\section{References}

Agência Brasileira de Promoção de Exportação e Investimentos. (2012). Estatísticas gerais 2010/2012. Available from:

http://www.brazilianleather.com.br/index.php?option=com_content\&view=article\&id=1 66\&Itemid=101. Access in May 3, 2012.

Associação Brasileira das Indústrias de Calçados. (2011a). Cartilha - Indústria de Calçados do Brasil 2011. Abicalçados, São Paulo. Access in March 3, 2012, Available from: <http://www.brazilianfootwear.com.br/relatorios/exibe/219840> 
Braga, S. A., Miranda, L. C. (Eds.). (2002). Comércio e meio ambiente: uma agenda positiva para o desenvolvimento sustentável. Ministério de Meio Ambiente, Brasília.

Buljan, J. (1996). Pollution limits for discharge of tannery effluent in water bodies and sewers. World Leather November: 65.

Campos, S. H. (2006). A indústria de couros no Brasil: desempenho superior ao da indústria calçadista em 2006. Porto Alegre: Fundação de Economia e Estatística, 2006. Access in October 13, 2006. Available from:

$<$ http://www.fee.tche.br/sitefee/download/indicadores/34_02/6_parte.pdf\#search=\%22ci nco $\% 20$ paises $\% 20$ produtores $\% 20$ couro $\% 202004 \% 202005 \% 22>$

Castro, D. et al. (2003). O comércio e meio ambiente - as diversas faces desse binômio. Centro de Estudos Avançados em Economia Aplicada, Piracicaba.

Castro, D., Castilho, S. \& Miranda, S.(2004). A rotulagem ambiental no contexto de comércio internacional. Centro de Estudos Avançados em Economia Aplicada, Piracicaba.

Clariant do Brasil. (2006). Tingimento: aspectos atuais. São Paulo.

Comissão das Comunidades Europeias. (2002). Decisão da comissão de 18 de março de 2002 que estabelece critérios ecológicos revistos para a atribuição do rótulo ecológico comunitário ao calçado e que altera a Decisão 1999/179/CE. Jornal Oficial das Comunidades Europeias, 20 mar.

Companhia de Tecnologia Ambiental de São Paulo. (2011). Câmara ambiental da indústria de couros, peles, assemelhados e calçados. Access in April 23, 2012, Available from: $<$ http://www.cetesb.sp.gov.br/tecnologia-ambiental/cas-em-atividade/44-camaraambiental-da-industria-de-couros--peles--assemelhados-e-calcados>

Contador Junior, O. (2004). Tecnologia e proteção ambiental nas indústrias do couro e calçados na região de Jaú-SP. Dissertação (Mestrado) - Centro Universitário de Araraquara, Araraquara. 163p.

Desai, P. N. (1995). Technology assessment in the Indian footwear sector. Technological Forecasting and Social Change, Vol. 48, No 2, pp. 177-187, ISSN 0040-1625.

Dexheimer, M. A. (2006). Riscos do cromo hexavalente no couro. Revista do Couro, Estância Velha, ed. 186, pp.102-104.

Ecoetiqueta Europea Para el Calzado. (2006). Ficha resumen. Access in March 30, 2012, Available from: <http://www.life-ecofoot.inescop.es/>

Food and Agriculture Organization. (2001). World statistical compendium for raw hides and skins, leather and leather footwear 1982-2000. Rome: Food and Agriculture Organization of the United Nations.

Fernandes, A. P. Política industrial trava a cadeia produtiva do couro. (2004). Couro News, July 7, 2004. Access in July 18, 2006. Available from:

<http://www.couro.news.com.br/Perfil\%20do\%20Setor/view.htm?id=217304\&ca_id=19>

Fornasari Filho, N., Coelho, L. R. (2002). Aspectos ambientais do comércio internacional. Federação das Indústrias de São Paulo, São Paulo.

Garrido, A. E. (2004). As barreiras técnicas ao comércio internacional. Instituto Nacional de Metrologia, Normalização e Qualidade Industrial, Rio de Janeiro. Access in March 31, 2005, Available from: <http://www.inmetro.gov.br/infotec/artigos/docs/51.pdf> 
Gaspar, L. G. (2006). Ciesp - Centro das Indústrias do Estado de São Paulo Regional Franca. May 3, 2006. Interviewed by Alexandre Bos, Mauro Silva Ruiz, Regina Nagamine e Luis Carlos Faleiros.

Girolla F. (2006). SENAI - Centro Tecnológico do Calçado. Novo Hamburgo, April, 4, 2006. Interviewed by Alexandre Bos, Mauro Silva Ruiz, Regina Nagamine e Luis Carlos Faleiros.

Glasspool, J. (2006). Substâncias nocivas: atualização quanto à comercialização e usos. Revista Tecnicouro, Novo Hamburgo, Vol. 27, No. 8, pp.68-71.

Gorini, A. P. F., Siqueira, S. H. G. (2002). Complexo coureiro - calçadista. Comércio Exterior. Access in May 1, 2012. Available from:

http://www.bndes.gov.br/SiteBNDES/export/sites/default/bndes_pt/Galerias/Arquivos/ conhecimento/bnset/bsespcal.pdf

Gutterres, M. (2005). Tendências emergentes da indústria do couro. Porto Alegre: UFRGS, Access in October 13, 2006. Available from: $<$ http://www.enq.ufrgs.br/pos/projetos/curtumes/Arqs/WPM\$6F4A.pdf\#search=\%22tab ela\%20produ\%C3\%A7\%C3\%A3o\%20mundial\%20couro\%22/>

Hoinacki, E.; Moreira, M. V. \& Kiefer, C. G. Manual básico de processamento do couro. Porto Alegre: Senai, 1994. 402p.

Instituto de Pesquisas Tecnológicas. (2006). Observatório de tecnologia e inovação (OTI): barreiras ao comércio internacional de couros e calçados - desafios para o enfrentamento das barreiras técnicas atuais e futuras. Relatório técnico. IPT, São Paulo. Vol. 2.

Instituto Nacional de Metrologia, Normalização e Qualidade Industrial. (2005). Barreiras técnicas às exportações: o que são e como superá-las. Inmetro, Rio de Janeiro. Access in April 9, 2012, Available from: <http://www.inmetro.gov.br/barreiras técnicas>

International Standardization Organization. (2011). ISO Survey of certifications 2010. Geneve: ISO, [CD-ROM].

Kolomaznika, K.,Adameka, M., Andelb I.\& Uhlirova, M. (2008). Leather waste - Potential threat to human health, and a new technology of its treatment. Journal of Hazardous Materials. Elsevier. 160, pp. 514-520.

Ministério do Desenvolvimento, Indústria e Comércio Exterior. (2002). Barreiras técnicas: conceitos e informações sobre como superá-las. Confederação Nacional da Indústria, Brasília.

Perina, M. A., Machado, R. Q. \& Miranda, S. H. G. (2003). As notificações do Brasil no acordo TBT e a importância das normas técnicas no comércio internacional. Centro de Estudos Avançados em Economia Aplicada, Piracicaba.

Philip, A., Jeanet, B. \& Finn, T. (2009). Trade and development: lessons from Vietnam's past trade agreements. World Development, Vol. 37, No. 2, pp. 341-353, ISSN 0305-750X.

Porter, M. E., Van Der Linde, C. (1995). Green and competitive: ending the stalemate. Harvard Business Review. Boston: Sep./Oct. 1995. Vol. 73, ISS. 5b; pp. 120 - 134.

Prazeres, T. L. (2003). Comércio internacional e protecionismo: as barreiras técnicas na OMC. Aduaneiras, São Paulo.

Procópio Filho, A. (1994). Ecoprotecionismo: comércio internacional, agricultura e meio ambiente. Instituto de Pesquisa Econômica Aplicada, Brasília. 
Ramasami, T. et al. (1999) Beamhouse and tanning operations: process chemistry revisited. J. Soc. Leather Technol. Chem. 83:39.

Rosa, S. E. S., Corrêa, A. R. A indústria calçadista no Brasil. Rio de Janeiro: BNDES, 2006. 4p. (Informe Setorial). Access in October 10, 2006, Available from: $<$ http://www.bndes.gov.br/conhecimento/setorial/informe-01AI.pdf >.

Santos A. M. M. M. et al. (2002). Panorama do setor de couro no Brasil. BNDES Setorial, Rio de Janeiro, No. 16, pp. 57-84.

Saravanabhavan, S. et al. (2005). A source reduction approach: Integrated bio-based tanning methods and the role of enzymes in dehairing and fibre opening. Clean Technologies and Environmental Policy, Vol. 7, No 1, pp.3-14, ISSN 1618-9558.

Schneider, F. (2006). Rockport Brasil. Campo Bom, 05 abr. 2006. Interviewed by Alexandre Bos, Mauro Silva Ruiz, Regina Nagamine e Luis Carlos Faleiros.

Sousa, J. D. F.(2006). Peles, couros e resíduos. São Paulo: Edgard Blucher.

The New Zealand Ecolabelling Trust (2006). EC-31-06 License criteria for textiles, skins and leather. Auckland, Access in April 2, 2012, Available from:

$<$ http://www.environmentalchoice.org.nz/docs/products_services/textiles_skins_leather /ec3106textilesskinsleather.pdf>

Wolf, G.; Schuck, F. (2003). Substâncias nocivas no couro - um panorama atual. XVI Congresso Nacional da ABQTIC, 16, Foz do Iguaçu, Anais...Foz do Iguaçu: ABQTIC.

World Bank.(1999). Tanning and leather finishing. In: Pollution prevention and abatement handbook 1998, Washington, D.C.: World Bank Group, p 404. 